\title{
HUBUNGAN PROFESI ORANG TUA DENGAN KEMANDIRIAN BELAJAR SISWA KELAS XI SMK NURUL HUDA PADANG TUALANG TAHUN PELAJARAN 2018 / 2019
}

\author{
Hadi Widodo, Fikri Ramadana \\ STKIP Budidaya Binjai
}

\begin{abstract}
ABSTRAK
Seiring dengan hal itu banyak pertanyaan yang timbul mengapa orang tua khawatir anakanaknya tidak berprestasi, apakah motivasi belajarnya 2 rendah atau mutu pendidikan di sekolah yang kurang baik atau aktivitas orang tua yang terlalu sibuk sehingga sedikit waktu untuk belajar bersama mereka. Jenis penelitian yang digunakan dalam penelitian ini adalah penelitian deskriptif. Populasi dalam penelitian ini adalah seluruh siswa kelas XI Nurul Huda Padang Tualang yang berjumlah 35 orang. Apabila jumlah subjeknya kurang dari 100 maka lebih baik diambil semua sehingga penelitiannya merupakan penelitian populasi. Jadi dapat disimpulkan bahwa nilai $r_{\text {hitung }}>r_{\text {tabel }}$ sehingga Ho ditolak, dan Ha diterima maka ada hubungan antara profesi orang tua dengan Kemandirian Belajar siswa kelas XI SMK Nurul Huda Padang Tualang tahun pelajaran 2018/2019. Nilai rata-rata hasil angket/kusioner profesi orang tua sebesar 38,9 sedangkan nilai ratarata angket/kusioner Kemandirian Belajar siswa sebesar 37,7.Dari hasil perhitungan di dapat $r_{\text {hitung }}$ sebesar 0,374 sedangkan pada $r_{\text {tabel }}$ taraf 5\% sebesar 0,334. Jadi dapat di simpulkan bahwa nilai $r_{\text {hitung }}>r_{\text {tabel }}$ sehingga Ho ditolak dan Ha diterima maka ada hubungan antara profesi orang tua dengan Kemandirian Belajar siswa kelas XI SMK Nurul Huda Padang Tualang tahun pelajaran 2018/2019.
\end{abstract}

Kata Kunci : Profesi orang tua kemandirian belajar

\section{PENDAHULUAN}

Keluarga adalah faktor utama dalam keberhasilan prestasi belajar siswa akademik maupun non akademik. Menurut Soelaeman dalam Shochib (2000:17) dalam pengertian psikologis, keluarga adalah sekumpulan orang yang hidup bersama dan masing-masing anggota merasakan adanya pertautan batin sehingga terjadi saling mempengaruhi, saling memperhatikan dan saling menyerahkan diri. Keluarga adalah faktor utama dalam keberhasilan prestasi belajar siswa akademik maupun non akademik. Dalam pengertian psikologis, keluarga adalah sekumpulan orang yang hidup bersama dan masing-masing anggota merasakan adanya pertautan batin sehingga terjadi saling mempengaruhi, saling memperhatikan, dan saling menyerahkan diri.

Shochib (2000:18) mengemukakan bahwa keluarga adalah satu persekutuan hidup yang dijalin oleh kasih sayang antara pasangan dua jenis manusia yang dikukuhkan dengan pernikahan, yang bermaksud untuk saling menyempurnakan diri. Dalam usaha saling melengkapi dan saling menyempurnakan diri itu terkandung perealisasian peran dan fungsi sebagai orang tua. Pendidikan dimulai dari lingkungan keluarga kemudian 
lingkungan sekolah. Sekolah sebagai lembaga pendidikan yang dipercaya oleh orang tua untuk mendidik anak-anaknya dalam jangka waktu cukup lama.

Sementara itu orang tua yang pekerjaanya yang membutuhkan waktu tidak lama, misalnya PNS, Guru, Pedagang yang memungkinkan mereka untuk bertemu keluarga bisa setiap hari.sehingga memiliki waktu lebih lam adalam memperhatikan perkembangan anaknya di rumah, dengan ketimpangan tersebut, perlu dilakukan penelitian berkenaan dengan kemandirian belajar, sebagaimana kita ketauhi bersama bahwa kemandirian belajar merupakan salah satu faktor internal yang mempengaruhi keberhasilan belajar siswa. Dalam Akhasanul Tahar dan Enceng (2006:93) menyampaikan bahwa ada beberapa pengertian dari kemandirian belajar. Pertama, kemandirian belajar adalah aktivitas belajar yang dilakukan oleh seseorang dengan kebebasannya dalam menentukan dan mengelola sendiri bahan ajar, waktu, tempat, dan memanfaatkan sumber belajar yang diperlukan.

\section{METODE}

Jenis penelitian yang digunakan dalam penelitian ini adalah penelitian deskriptif. Populasi dalam penelitian ini adalah seluruh siswa kelas XI Nurul Huda Padang Tualang yang berjumlah 35 orang. Apabila jumlah subjeknya kurang dari 100 maka lebih baik diambil semua sehingga penelitiannya merupakan penelitian populasi. Jumlah populasi hanya sebanyak 35 orang siswa atau sebanyak siswa maka semua menjadi sampel.

Untuk mengetahui hubungan antara pola asuh orang tua otoriter terhadap agresivitas siswa dengan menggunakan rumus validitas instrumen korelasi product moment yaitu untuk menentukan hubungan antara dua gejala interval. Teknik analisis data yang dilaksanakan dalam pengolahan data sebagai berikut:

a. Pemeriksaan dan pemberian nilai pada setiap kusioner/angket dan hasil tes.

b. Menghitung hasil nilai kusioner/angket pada setiap variabel yang dijadikan sampel dengan simbol X, $\mathrm{X}^{2}$ dan XY.

c. Menghitung hasil nilai dengan menggunakan simbol $\mathrm{Y}, \mathrm{Y}^{2}$ dan $\mathrm{XY}$.

d. Menghubungkan kedua nilai tersebut dengan menggunakan rumus korelasi product moment

\section{HASIL PENELITIAN DAN PEMBAHASAN}

Setelah data-data yang penulis kumpulkan lengkap, maka selanjutnya peneliti mengadakan analisis ada atau tidaknya hubungan antara profesi orang tua $(\mathrm{X})$ dengan Kemandirian Belajar siswa (Y), maka data-data yang diperoleh dianalisis dengan 
menggunakan rumus korelasi product moment. Adapun langkah-langkah untuk memudahkan jalannya analisis yaitu dengan melalui tahapan:

1. Deskripsi data hasil penelitian

2. Pengujian hipotesis

3. Pembahasan hasil penelitian

4. Keterbatasan penelitian

\section{Deskripsi Data Angket/Kusioner Profesi Orang Tua}

Data yang terkumpul diperoleh dari hasil penelitian tentang profesi orang tua pada siswa kelas XI SMK Nurul Huda Padang Tualang dimana pada bagian ini akan disajikan hasil jawaban angket/kusioner yang disajikan pada siswa-siswa.

Dari tabel diatas yaitu tabel frekuensi tenteng hubungan profesi orang tua siswa kelas XI SMK Nurul Huda Padang Tualang telah diperoleh nilai sebagai berikut: untuk interval 33 - 35 dengan 2,8\%, untuk interval 36 - 38 dengan 54,3\%, untuk $39-41$ dengan $28,6 \%$, untuk interval $42-44$ dengan $8,6 \%$, dan untuk interval $45-47$ dengan $5,7 \%$.

\section{Deskripsi Data Angket/kusioner Kemandirian Belajar}

Dari data yang terkumpul diperoleh hasil penelitian tentang Kemandirian Belajar siswa kelas XI SMK Nurul Huda Padang Tualang dimana pada bagian ini akan disajikan hasil jawaban angket/kusioner yang disajikan. Pemberian angket ini disebar pada 40 orang siswa dan diambil 35 siswa yang menjadi sampel. .

Dari tabel diatas yaitu tabel frekuensi tentang Kemandirian Belajar siswa kelas XI SMK Nurul Huda Padang Tualang telah diperoleh sebagai berikut: untuk interval 32 - 34 dengan nilai 8,6\% , untuk interval 35 - 37 dengan nilai $37,1 \%$, untuk interval 38 40 dengan nilai $40 \%$, untuk interval 41 - 43 dengan nilai 11,5\% dan untuk interval 44 46 dengan nilai $2,8 \%$.

Untuk mengetahui kualitas masing-masing variabel, maka dapat ditempuh dengan rata-rata (mean) yaitu :

$$
\begin{aligned}
& \sum x=1.364 \\
& \overline{M X}=\frac{1.364}{35} \\
& \overline{M X}=38,9 \\
& \sum y=1.321
\end{aligned}
$$


$\overline{M Y}=\frac{1.321}{35}$

$\overline{M Y}=37,7$

Dengan demikian hasil dari nilai kualitatif untuk variabel $\mathrm{X}$ apabila diterapkan interval nilai, maka menduduki interval 36 - 38 dan termasuk kualitas sedang. Sedangkan hasil nilai kualitatif untuk variabel $\mathrm{Y}$ apabila diterapkan pada variabel nilai, maka menduduki interval antara 35 - 37 dan termasuk dalam kualitas sedang.

Dari hasil perhitungan di dapat $r_{\text {hitung }}$ sebesar 0,374 sedangkan $r_{\text {tabel }}$ pada taraf 5\% sebesar 0,334. Jadi disimpulkan bahwa nilai $r_{\text {hitung }}>r_{\text {tabel }}$ sehingga Ho ditolak, dan Ha diterima maka ada hubungan antara profesi orang tua dengan Kemandirian Belajar siswa kelas XI SMK Nurul Huda Padang Tualang tahun pelajaran 2018/2019.I

\section{SIMPULAN}

Dari hasil pembahasan penelitian dapat disimpulkan bahwa:

1. Nilai rata-rata hasil angket/kusioner profesi orang tua sebesar 38,9 sedangkan nilai rata-rata angket/kusioner Kemandirian Belajar siswa sebesar 37,7.

2. Dari hasil perhitungan di dapat $r_{\text {hitung }}$ sebesar 0,374 sedangkan pada $r_{\text {tabel }}$ taraf $5 \%$ sebesar 0,334. Jadi dapat di simpulkan bahwa nilai $r_{\text {hitung }}>r_{\text {tabel }}$ sehingga Ho ditolak dan Ha diterima maka ada hubungan antara profesi orang tua dengan Kemandirian Belajar siswa kelas XI SMK Nurul Huda Padang Tualang tahun pelajaran 2018/2019.

\section{REFERENSI}

. Prosedur Penelitian Suatu Pendekatan Praktik, Jakarta :

PT Rineka Cipta, edisi revisi, 2006.

Akhsanul Bashari, Hubungan Bimbingan Karir Dan Kematangan Dengan

Motivasi Bekerja Pada Siswa Program Keahlian Teknik Instalasi Tenaga Listrik SMK di Kulon Progo (2012).

http://digilib.unsby.ac.id/9945/4/bab\%201.pdf. Diakses pada tanggal 10 Juli 2017.

Moh. Shochib, Pola Asuh Orang Tua Jakarta : Rineka Cipta, 2000. 